\title{
THE REAL WINNERS : APLIKASI KNOWLEDGE MANAGEMENT DALAM INDUSTRI PERBANKAN NASIONAL
}

\author{
Heri Yuliyanto
}

Laboratorium Akuntansi Program Vokasi UI, heri.aqwam@gmail.com

\section{Diterima : 13 November 2015}

Layak Terbit : 1 Januari 2016

\begin{abstract}
Abstrak
Penguasaan teknologi informasi merupakan hal penting bagi industri perbankan yang memiliki struktur pasar oligopoli ${ }^{1}$, tetapi tidak memberikan jaminan keunggulan daya saing yang berkelanjutan. Untuk memenangkan persaingan bukan hanya ditentukan oleh teknolgi dan harga (bunga yang diberikan), tetapi juga faktor penguasaan knowledge dan informasi yang saat merupakan isu yang sangat strategis.

Jika sebuah bank menggunakan teknologi sebagai keunggulan daya saingnya, maka keunggulan itu akan bersifat sementara, karena teknologi mempunyai sifat mudah ditiru. Namun demikian, jika keunggulan teknologi informasi disertai dengan penguasaan informasi dan pengelolaan knowledge yang berkualitas, maka pesaing memerlukan usaha yang lebih besar dan waktu yang lama untuk bisa meniru atau menduplikasi keunggulan daya saing tersebut. Dengan demikian keunggulan daya saing tersebut akan berlangsung lebih lama.

Melalui studi pustaka dan analisa data sekunder diperoleh informasi bahwa prospek pasar perbankan nasional masih luas. Disamping itu, faktor teknologi bukan merupakan faktor utama yang menjadi daya tarik atau alasan bagi nasabah untuk memiliki rekening di bank, tetapi image banknya aman merupakan alasan utama untuk memiliki rekening.
\end{abstract}

Kata kunci; Knowledge Management, MEA, keunggulan daya saing, strategi bersaing

\begin{abstract}
Mastery of information technology is important for the banking industry has an oligopoly market structure, but does not guarantee a sustainable competitive advantage. To win the competition is not only determined by the technologically and price (interest given), but also factors mastery of knowledge and information an currently issue that is very strategic. If a bank uses technology as an advantage its competitiveness, then the advantage will be temporary, because the technology has the properties easily imitated. However, if the advantages of information technology along with the mastery of information and knowledge of quality management, the competitors require greater effort and a long time to be able to imitate or duplicate the competitive advantage. Thus the competitive advantage that will last longer. Through literature study and analysis of secondary data obtained information that the national banking market outlook is still widespread. In addition, the technology factor is not the major factor is the main attraction or reason for customers to have a bank account, but the image bank safe is the main reason to have accounts.
\end{abstract}

Keyword; Knowledge Mangement, MEA , competitive advantege, competitive strategy

1 Menurut MASR 2008, pangsa pasar BCA 34,4\%, BRI 27,6\%, BNI 19,1\% dan Mandiri 15,1\%. Total pangsa pasar ke 4 bank adalah $96,2 \%$ 


\section{PENDAHULUAN}

Internet merupakan salah satu bentuk teknologi informasi yang akhir dekade ini menjadi isu utama pembicaraan semua orang, organisasi bisnsi dan media masa. Karena perkembangan teknologi informasi (Internet) telah mampu merubah bagaimana individu maupun organisasi dalam menjalankan aktivitasnya.

Masih belum lupa dari ingatan kita beberapa bulan yang lalu, tepatnya ketika proses pemilihan presiden di negara pengusung konsep demokrasi (Amerika Serikat) dilakukan. Dan strategi apa yang dipakai oleh pemenang pemilu presiden tersebut, yaitu Barack Obama.

Dengan memperhatikan proses pemilihan presiden di Amerika Serikat tersebut, dapat dilihat bagaimana pengaruh kekuatan teknologi informasi pada proses pemilihan umum dan strategi yang diterapkan oleh Barack Obama untuk memenangkan pertarungan pemilihan presiden. Dan momen ini telah membuat sejarah baru di Amerika Serikat, sejarah baru tersebut adalah Barack Obama merupakan presiden pertama dari keturunan kulit hitam yang memenangkan proses pemilihan presiden yang demokratis. Semua itu tidak lepas dari strategi pemanfaatan teknologi informasi untuk kampanye penguasaan publik ataupun penggalangan dana. Sebenarnya, strategi ini hampir sama dengan strategi yang dilakukan oleh Franklin Delano Roosevelt yang menggunakan radio dan John F Kennedy yang memanfaatkan televisi untuk menggapai kemenangan. Obama telah berhasil memindahkan politik kepresidenan masuk ke dunia digital ${ }^{2}$.

Dari politik, kita pindah ke industri, hampir semua sektor industry akan dipengaruhi perkembangan teknologi informasi. Di industri ritel misalnya, Raja Ritel kelas dunia (Wall Mart) mencoba mengimplementasikan konsep Self Service Kiosk dengan menggunakan teknologi RFID ${ }^{3}$ untuk melayani pelanggan yang datang belanja ke toko (Turban, 2004). Demikian juga di industri pendidikan, dengan aplikasi akademik on line ataupun e-learning yang dikenal dengan istilah pembelajaran jarak jauh, telah menjadi alternatif proses pembelajaran saat ini. Di industri perbankan dengan Anjungan Tunai Mandiri (ATM) ataupun Internet Banking dijadikan alternatif layanan kepada nasabah.

Pengaruh teknologi informasi dalam skala yang lebih luas adalah globalisasi. Teknologi informasi telah mempercepat terjadinya globalisasi, baik globalisasi informasi, politik, budaya maupun ekonomi. Batas suatu wilayah atau perbedaan waktu antar wilayah bukan lagi sebagai hambatan untuk melakukan transaksi atau komunikasi. Bagaimana peristiwa di belahan bumi utara bisa disaksikan secara langsung di belahan bumi selatan dengan memanfaatkan teknologi satelit. Aliran modal asing baik yang masuk

2 "Ampuhnya Kekuatan Internet", http://www.kompas/read/xml/2008/11/06/063 82584/ampuhnya.kekuatan.internet

3 RFID adalah teknologi frekuensi radio yang digunakan untuk mengidentifikasi setiap barang yang dibeli oleh pelanggan pada perusahaan ritel secara otomasi. 
ke negara atau keluar dari negara bisa terjadi kapan saja dan dilakukan dengan mudah.

Dengan melihat ilustrasi tersebut maka dapat ditarik kesimpulan bahwa industri dapat menggunakan teknologi informasi untuk membantu strategi perusahaan dalam memenangkan suatu persaingan. Namun yang menjadi pertanyaan adalah sampai berapa lama keunggulan teknologi ini bisa dipertahankan? Bagaimana kalau pesaing kita meniru teknologi yang kita gunakan dan kemudian melakukan penyempurnaan untuk balik menyerang kita? Itu semua sangat mungkin dilakukan, karena perkembangan teknologi sangat cepat dan terbuka.

Lalu strategi apa yang bisa digunakan untuk memenangkan persaingan dan keunggulan bisa bertahan lama karena pesaing akan mengalami kesulitan untuk meniru atau menduplikasi keunggulan kita? Dengan demikian keunggulan kita akan bisa bertahan lama dan berkelanjutan.

\section{Knowledge Management}

Hidayat, J. T. dan Doanld Crestofel Lantu mengatakan bahwa ilmu pengetahuan (knowledge) merupakan kebutuhan mendasar bagi setiap individu. Jika knowledge seseorang tidak berkembang maka orang tersebut tidak bisa menyelesaikan masalahnya, karena masalah dari hari ke hari akan berkembang dan berbeda, sehingga menuntut knowledge yang berbeda pula untuk menyelesaikannya.

$$
\text { Demikian juga perusahaan, }
$$
perusahaan tidak akan mampu bertahan dan bubar jika individu yang ada didalamnya tidak mau dan mampu belajar untuk mendapat ilmu pengetahuan yang baru untuk merespon perubahan lingkungan yang cepat dan tidak menentu.

Menurut Alvin Tofler, saat sudah memasuki era pengetahuan, dimana ilmu pengetahuan sangat dominan dalam mengelola sebuah organisasi. Kemampuan bersaing sebuah organisasi, sangat ditentukan bagaimana kualitas teknologi dan ilmu pengetahuan yang dimiliki dapat diinternalisasikan melalui proses bisnis organisasi untuk menghasilkan produk/jasa berkualitas. Organisasi yang mampu mengelola ilmu pengetahuannya, yang meliputi tacit dan explicit kemudian menginternalisasikan dalam setiap aktivitas organisasi akan berdampak pada proses produksi yang efisien dan menghasilkan produk atau jasa yang berkualitas. Knowledge (ilmu pengetahuan) terdiri dari dua jenis, yaitu explicit knowledge dan tacit knowledge. Explicit knowledge adalah ilmu pengetahuan yang diwujudkan dalam suatu dokumen, baik dokumen berbasis elektronik ataupun berbasis kertas. Sedangkan tacit knolwledge adalah ilmu pengetahuan yang berada pada memorimemori individu yang menjalankan bisnis. Kedua jenis ilmu pengetahuan ini harus bisa dimanfaatkan oleh organisasi secara bersamasama, walaupun pada kenyataan pengelolaan tacit knowledge lebih sulit dilakukan jika dibandingkan dengan explicit knowledge. Definisi knowledge management sangat beragam, misalnya Laudon dalam bukunya Management Information Systems mendefinisikan knowledge management dengan kumpulan proses yang dilakukan dalam 
sebuah organisasi untuk menciptakan, mengumpulkan, memelihara dan menggunakan ilmu pengetahuan perusahaan (Laudon, 2004). Sedangkan Kirk Klasson dalam bukunya The Management Knowledge Kit mengatakan - Knowledge management is the ability to create and retain greater value from core business competencies (Tiwana, 2000). Walupun ada beberapa perbedaan definisi, namun secara garis besar mempunyai kesamaan. Knowledge management berhubungan dengan masalah bisnis dalam suatu perushaaan, seperti proses untuk menghasilkan inovasi produk atau jasa, pengelolaan dan pengembangan hubungan patner bisnis, meningkatkan mutu layanan dengan pelanggan ataupun peningkatan proses kerja agar lebih efisien dan efektif.

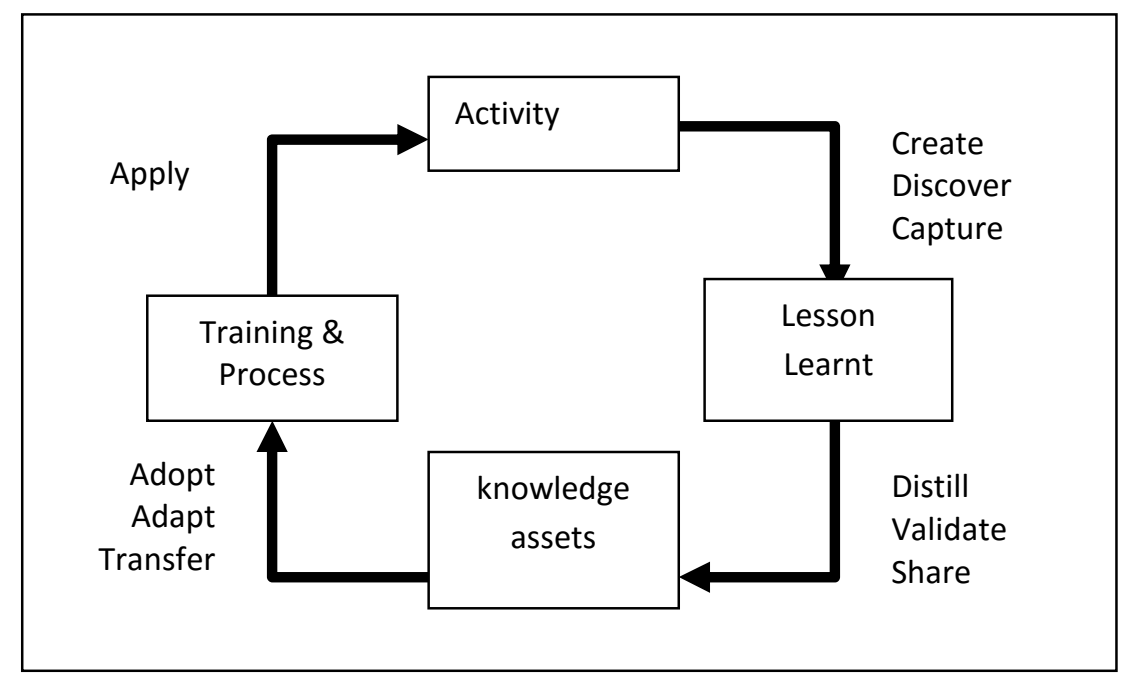

Gambar 1. Aktivitas-Aktivitas Knowledge Managemenet Sumber : Collison and Parcell, 2004

Collison dan Parcell menjelaskan aktivitas knowledge management terdiri dari create, discover, dan capture kemudian dilanjutkan dengan distil, validate dan share, dan adopt, adopt dan transfer dan terakhir adalah apply, seperti gambar diatas (Collison, 2004)

\section{Diskusi}

\section{Peluang dan Tantangan}

Globalisasi merupakan peluang (opportunity) dan sekaligus tantangan bagi semua sektor industry, tak terkecuali perbankan nasional kita. Peluang dalam hal ini adalah terbukanya pasar yang lebih luas, karena pasar tidak terikata pasar-pasar local atau nasional, tetapi mencakup pasar internasional. Sedangkan yang dimaksud dengan tantangan disini adalah dengan adanya globalisasi, maka investor asing atau perbankan asing bisa melakukan aktivitas (beroperasi) di Indonesia. Hal ini akan merubah peta persaingan industry perbankan nasional yang lebih ketat yang berdampak mengancam keberadaan perbankan nasional, 
jika tidak dilakukan antisipasi sedini mungkin. Lalu strategi apa yang bisa digunakan untuk memenangkan persaingan yang berkelanjutan?

Prosentase jumlah masyarakat Indonesia pada tahun 2007 yang memiliki rekening di Bank memberikan informasi bahwa pasar perbankan nasional masih memberikan potensi yang cukup besar. Hal ini ditunjukan bahwa rata-rata jumlah konsumen Indonesia tahun 2007 yang memiliki rekening di Bank sebesar 37,6\% (seperti tabel 1). Angka ini relative masih jauh dari $50 \%$, dan kemugkinan besar masih bisa turun jika pengamatan dilakukan diseluruh kota Indonesia. Karena survei ini hanya mencakup 5 kota besar di Indonesia, yaitu Jakarta, Bandung, Semarang, Surabaya dan Medan.

Dari 5 kota besar tersebut, Jakarta memimpin dengan angka $41,7 \%$ disusul Surabaya dengan prosentase 40,6\% baru kota-kota besar lainnya. Angka-angka prosentase ini mempunyai kecenderungan akan semakin turun, karena kota-kota lainnya mempunyai infrastrukur perbankan yang lebih jelek.

Tabel 1 : Jumlah Konsumen Indonesia 2007 yang Memiliki Rekening di Bank

\begin{tabular}{|l|l|l|l|l|l|}
\hline Jakarta & Bandung & Semarang & Surabaya & Medan & Total \\
\hline $41,7 \%$ & $23,2 \%$ & $35,0 \%$ & $40,6 \%$ & $31,9 \%$ & 37,6 \\
\hline
\end{tabular}

Sumber : Penelitian Mars, 2006

Dengan melihat masih terbukanya peluang pasar di Indonesia (37,6\%) dan semakin terbukanya sistem ekonomi (globalisasi), berdampak semakin ketat persaingan dunia perbankan yang akan menentukan strategi apa yang memberikan keunggulan jangka berkelanjutan? Ini merupakan pertanyaan yang menarik untuk dikaji dan memerlukan penelitian untuk memperolah jawabannya.

Kemampuan daya saing sebuah organisasi, sangat ditentukan bagaimana kualitas ilmu pengetahuan yang dimiliki dapat diwujudkan dalam bentuk produk/jasa maupun aktivitas proses bisnis organisasi
(Yuliyanto, 2006). Pada era pengetahuan ini, keunggulan daya saing sebuah perusahaan bukan terletak pada teknologi atau mesin yang digunakan, melainkan pada penguasaan knowledge dan informasi. Keunggulan teknologi tidak memberikan keunggulan yang berkelanjutan jangka panjang (Tiwana, 2008). Seperti pada kasus Citibank, teknologi hanya memberikan keunggulan daya saing sementara pada Citibank, yaitu ketika pertama kali meluncurkan penggunaan mesin ATM sebagai sarana memberikan layanan kepada nasabahnya. Karena beberapa waktu kemudian banyak pesaing yang menggunakan teknologi yang sama dengan melakukan 
perbaikan teknologi (Tiwana, 2008). Dengan demikian hilanglah keunggulan daya saing Citibank, karena para pesaing telah menggunakan teknologi yang sama dengan melakukan perbaikan. Oleh karena itu Citibank harus melakukan pengelolan knowledge dan informasi untuk melakukan inovasi proses dan produk, sehingga pesaing sulit untuk menduplikasi keunggulan daya saing tersebut.

Menurut data survei yang dilakukan oleh MARS ( pada grafik 1), menunjukkan bahwa alasan banknya aman mempunyai prosentase paling besar sebagai pertimbangan untuk memiliki rekening, yaitu 20\%, kemudian disusul dengan alasan banknya dekat dengan rumah (14\%) dan peringkat ketiga adalah ditentukan oleh kantor tempat bekerja untuk keperluan penggajian (payroll). Yang menarik untuk dikaji lebih dalam adalah pelayanan yang memuaskan mempunyai prosentase sebesar $11 \%$ berada di peringkat ke 4 bersama-sama dengan banknya terpercaya, banknya dekat dengan kantor dan cabangnya banyak, sedangkan alasan lainnya $9 \%$.

Fasilitas layanan perbankan (channel) yang paling sering digunakan untuk melakukan transaksi di bank, khususnya menarik tabungan adalah ATM, kemudian dilanjutkan secara berturut-turut adalah Kantor Cabang, Merchant (Hypermarket/Minimarket) dan terakhir adalah kantor pusat (untuk lebih detil lihat lampiran 4). Hal ini menunjukkan bahwa ATM merupakan channel yang paling favorit bagi nasabah untuk melakukan transaksi, sedangkan Internet Banking/Mobile Banking belum menjadi pilihan utama bagi nasabah untuk melakukan transaksi. Hal ini disebabkan pengetahuan (awarness) konsumen tentang Internet banking untuk kota-kota di Indonesia, seperti Surabaya dan Jakarta masih sangat rendah, yaitu sekitar 33,1\%, apalagi kalau survei dilakukan secara nasional diseluruh wilayah Indonesia, maka angka yang didapatkan akan lebih kecil. Dari 33,1\% yang sudah mengetahui internet bangking hanya $7,5 \%$ yang memiliki Internet Banking, angka ini masih jauh lebih kecil jika dibanding dengan prosentase konsumen yang mengenal Internet banking. Hal ini menunjukkan bahwa konsumen masih enggan untuk memiliki Internet banking yang kemungkinan besar disebabkan oleh faktor keamanan transaksi menggunakan internet banking.

\section{Kualitas Layanan}

Pada saat ini prosentase para nasabah menjadikan kualitas layanan sebagai alasan utama untuk memiliki rekening tabungan masih rendah, hanya sekitar $11 \%$. Alasan memiliki rekening masih didominasi oleh banknya aman, untuk keperluan penggajian dan lokasinya dekat dengan rumah. Dengan demikian masih ada peluang bagi pelaku di industri perbankan untuk meningkatkan kualitas layanan guna menarik dan mempengaruhi para calon nasabah untuk bersedia membuka rekening tabungan di bank

Jika rata-rata prosentase jumlah nasabah di Indonesia adalah 36,7\% dan jumlah penduduk Indonesia adalah 200 juta, maka masih ada 126.600.000 calon nasabah potensial. 


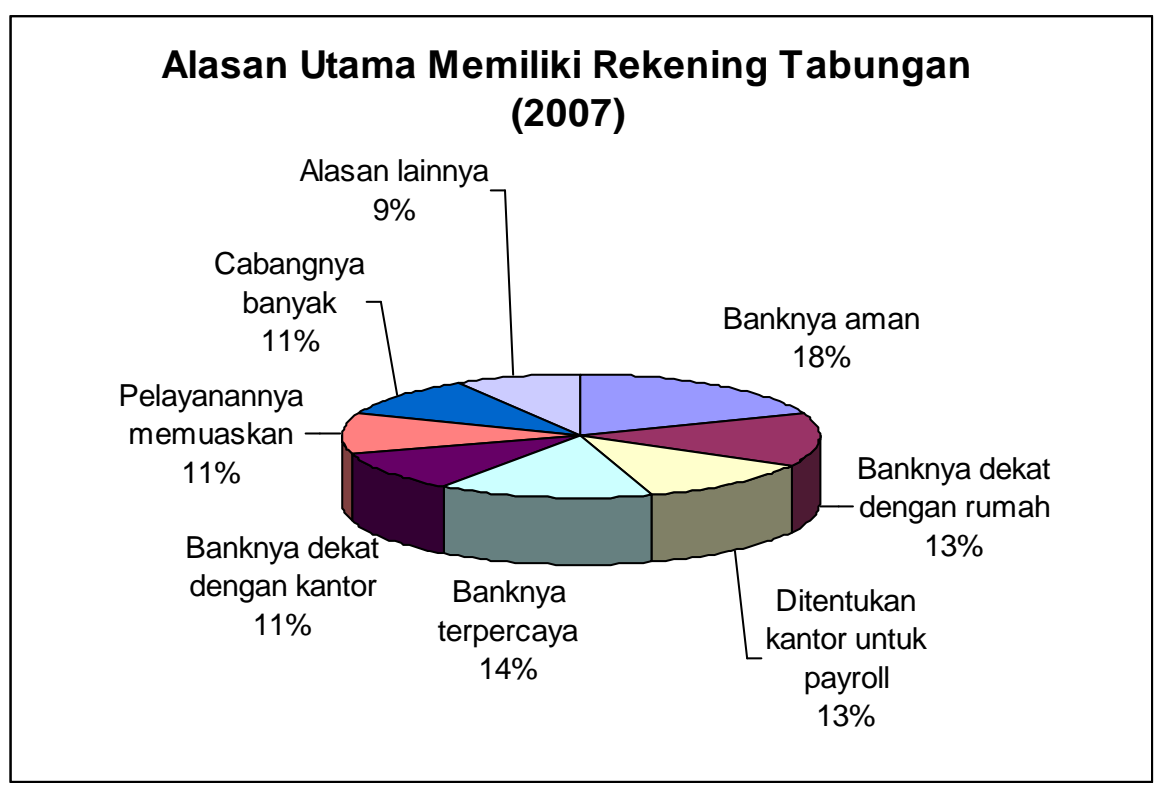

Grafik 1: Pertimbangan Kepemilikan Rekening Tabungan

Oleh karena itu, perusahaan perlu mendorong setiap individu di dalam perusahaan untuk selalu menambah pengetahuan mereka untuk melahirkan knowledge worker. Dengan didukung oleh knowledge worker maka akan melahirkan inovasi produk dan layanan yang akan bermuara pada kualitas pelayanan dan berdampak pada peningkatan kepuasan nasabah.

\section{Penguasaan Knowledge dan Informasi}

Pada, masa yang akan datang kekuatan daya saing perusahaan termasuk perbankan bukan terletak pada teknologi yang dimiliki, melainkan pada knowledge yang dimiliki oleh instansi yang bersangkutan, hal ini senanda dengan pemikiran Alvin Tofler dan Peter Drucker. Karena pada suatu saat nanti, pekerjaan rutin dan bersifat klerikal akan digantikan oleh teknologi, sehingga yang dibutuhkan tenaga dari manusia adalah proses berfikir dan knoweledge yang dimiliki. Karena teknolgi sulit bisa menggantikan knowledge dan proses berfikir yang dimiliki oleh manusia. Lima belas tahun yang lalu, tidak terbayangkan jika layanan pengambilan uang, transfer, pembayaran tagihan dan lainlainnya bisa digantikan oleh teknologi seperti ATM atau internet banking yang menggantikan tenaga teller (manusia). Dengan demikian kebutuhan tenaga manusia akan semakin kecil.

Gambar 2 : Proses Pembentukan Keahlian

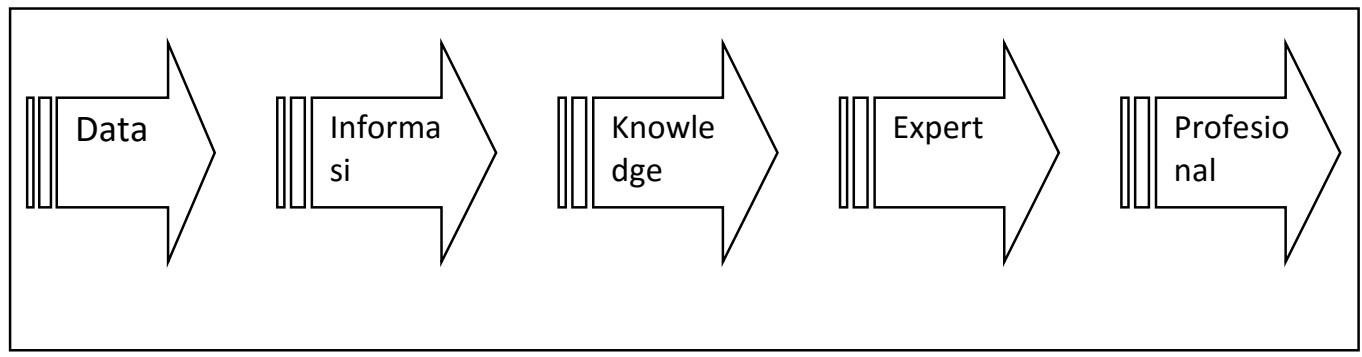


Perubahan pasar dan didorong oleh kebutuhan pelanggan (nasabah) membuat organisasi tergerak untuk mengelola pengetahuan yang dimiki perusahaan (Firdanianti, 2008). Dengan pengelolaan informasi dan knowledge yang baik, maka perusahan mempunyai tenaga ahli yang cukup profesional dan akan dapat merespon perubahan lingkungan yang cepat yang sering terjadi akhir dasa warsa ini. Dengan demikian keunggulan akan selalu berada di tangan mereka yang berada pada barisan terdepan dalam ilmu pengelolaan pengetahuan (Thomas A Stewart).

\section{Pasar Industri Perbankan}

Industri perbankan mempunyai karakteristik lingkungan yang menarik untuk dilihat sebagai pijakan dalam menentukan strategi perusahaan. Yang pertama adalah perbankan mengelola dan mengembangkan dana pihak ketiga yang berupa tabungan ataupun deposito. Yang kedua adalah dalam melakukan pengelolaan dana tersebut perbankan diikat oleh aturan yang dibuat oleh Bank Indonesia sebagai lembaga pemeritah yang membuat regulasi perbankan. Dengan melihat kondisi tersebut, maka ruang gerak Industri perbankan agak terbatas, karena ada aturan-aturan yang dibuat oleh Bank Indonesia yang harus dipenuhi, seperti diantaranya kecukupan modal minimum, suku bunga dan lain-lain.

Faktor eskternal lain yang menarik adalah adanya ekspansi investor dari Malaysia ke industri perbankan Indonesai. Pembelian BII dengan harga premium oleh Maybank memberikan sinyal kuatnya minat investor Malaysia untuk mengembangkan bisnis industri perbankan. Saat ini ada 5 bank milik investor Malaysia yang ada di Indonesia, yaitu Bank Maybank Indocorp, Bank Bumiputra Indonesia, Bank International Indonesia, Lippobank dan Bank Niaga. Bank-bank miliki investor Malaysia ini akan besrsaing dengan bank-bank Singapura yang beroperasi di Indonesia antara Lain Bank NISP, Bank OUB Buana, Bank DBS Indonesia, Bank OCBD Indonesia, dan Bank Danamon Indonesai (Infobank, Mei 2008).

Dengan dimilikinya beberapa bank oleh investor dari Singapura dan Malaysia yang diikuti dengan mergernya beberapa bank semakin menguatkan struktur pasar oligopoli industri perbankan nasional. Hal ini juga diperkuat oleh data survey yang dilakukan oleh MARS pads tahun 2008. Struktur pasar oligopoli bisa terbentuk jika hanya ada beberapa produsen yang menguasai pasar dan mempunyai kekuatan yang cukup besar untuk mempengaruhi harga pasar.

Disamping itu, strategi yang diambil oleh para penguasa pasar akan mempengaruhi strategi yang diambil oleh prodosen (bank) lainnya. Menurut Pratama Raharja dan Mandala Manurung, ada beberapa faktor penting berhubungan dengan karakteristik Pasar Oligopoli, yaitu pengambilan keputusan yang saling mempengaruhi (IndependenceDecision) dan kompetisi bukan pada harga (non pricing competition) (Pratama, 2002). Hal ini semakin memperkuat betapa pentingnya knowledge dalam memenangkan persaingan di era global dan 
terbuka seperti saat ini.

\section{Kesimpulan dan Saran}

Seiring dengan arus globalisasi, seperti MEA, AFTA dan lainnya, Pasar perbankan di Indonesai masih sangat menjanjikan, karena prosentase penduduk Indonesia yang memiliki rekening di bank masih rendah, demikian juga pengetahuan dan kepemilikan internet banking. Hal ini masih terbuka bagi industri perbankan mencari nasabah dan meningkatkan kualitas layanan perbankan.

Untuk memenangkan persaingan di industri perbankan bukan terletak pada harga (bunga yang diberikan) ataupun teknologi yang dimilikinya, melainkan pada sumber daya manusia (SDM) yang handal atau knowledge worker sejati yang dimilki oleh organisasi. SDM yang handal akan mendorong krativitas dan inovasi yang akan meningkatkan produktivitas.Untuk melahirkan knowledge worker sejati perlu didukung oleh lingkungan perusahaan yang kondusif dan motivasi yang tinggi dari semua pegawainya. Oleh karena itu sistem perusahaan yang baik dan konsisten dalam pelaksanaannya sangat diperlukan untuk membentuk knowledge worker yang akan berkerja dengan ilmu pengetahuan yang dimiliknya.Untuk menggali lebih jauh temuan dari peneltian ini disarankan untuk melakukan penelitian lebih lanjut dengan menggunakan data primer atau memperluas cakupan surevei data, sehingga informasi yang didapatkan lebih valid. Karena survei yang dilakukan oleh MARS hanya meliputi kota-kota besar di Indonesia, seperti Jakarta, Surabaya, Medan, Bali, Bandung, dan Surabaya.

\section{DAFTAR PUSTAKA}

(Collison, 2004) : Chris Collison and Geoff Parcell, "Learning to Fly : Practical Knowledge Management from Leading and Learning Organization”, Capstone Publishing Limited, 2004, page: 21

(Firdanianti, 2008) : Firdanianti, "Menumbuhkan Knowledge Management Dengan Kesadaran”, Human Capiptal Management, No. 53, Agustus 2008

(Infobank, Mei 2008) : Ekspansi Bank dari Malaysia dan Singapura : Adu Kuat Malaysia dan Singapura di Indonesia”, Infobank Edisi Mei 2008, hal: 30-31

(Laudon, 2004) : Kenneth C Laudon and Jane P Laudon, "Management Information Systems", Prentice Hall 2004, page: 315

(Pratama, 2002) : Pratama Raharja dan Mandala Manurung. : Teori Ekonomi Mikro Suatu Pengantar", Lembaga Penerbit Fakultas Ekonomi Universitas Indonesia, 2002 
(Tiwana, 2002) : Amrit Tiwana, "The Knowledge Management Toolkit : Practical Techniques for Building a Knowledge Management System”, Prentice Hall, 2000.

(Turban, 2004) : Efraim Turban, Dorothy Leidner, Ephraim McLean, and James Wetherbe, "Information Technology for Management: Transforming Organization in the Digital Economy", John Wiley \& Sons, 2004

(Yuliyanto, 2006) : Heri Yuliyanto, "Pengaruh Pengetahuan Kognitif dan Pelaksanaan Knowledge Management terhadap Penggunaan Knoewledge Management”, Proceeding Seminar Nasional Trisakti,2006 